\title{
Content Analysis of Research Trends in Instructional Design Models: 1999-2014
}

\author{
Idris Göksu \\ Mardin Artuklu University, Turkey \\ idrisgoksu@artuklu.edu.tr \\ Kursat Volkan Özcan \\ Gaziosmanpasa University, Turkey \\ kursatvolkan.ozcan@gop.artuklu.edu.tr \\ Recep Çakir \\ Amasya University, Turkey \\ recepcakir@amasya.edu.tr \\ Yuksel Göktas \\ Atatürk University, Turkey \\ yukselgoktas@atauni.edu.tr
}

\begin{abstract}
This study examines studies on instructional design models by applying content analysis. It covers 113 papers published in 44 international Social Science Citation Index (SSCI) and Science Citation Index (SCI) journals. Studies on instructional design models are explored in terms of journal of publication, preferred model, country where the study was conducted, research method, data collection tool, data analysis method, sampling interval, and field in which the model was applied. Studies are also examined in terms of variables, focusing on connections with model used, relevant results, and orientation of the model (e.g., system-oriented, class-oriented, or product-oriented). Results identified the most preferred models as ADDIE, ARCS, Gagne and Briggs, 4C-ID, and Dick and Carey. System-based instructional design models were most common. These results show recent trends in instructional design models and will contribute to both researchers and instructional designers.
\end{abstract}

\section{Keywords}

instructional design, instructional design model, ADDIE, content analysis

\section{Introduction}

Elaborate planning and arrangement of instruction is important for ensuring quality in education, which is its main goal. Instructional design leads the way in accomplishing this goal through better, more effective teaching. Instructional design, which gained more and more importance during the second half of the $20^{\text {th }}$ Century, has led to the development of many models to improve teaching as a result of technological advancements. According to Şimşek (2011), instructional design first appeared as a system in the 1950s via studies on instructional design models.

Instructional design has acquired various dimensions and been defined in different ways as a result 
of developing instructional technologies. For example, to Seels and Richey (1994), instructional design referred to the evaluation of processes and resources for facilitating the conceptualisation, development, implementation and management of learning. Valiathan (2010) observed how instructional design is affected by learning and motivation theories and highlighted certain elements for effective teaching. According to Reigeluth (1983), instructional design has three major components: methods, conditions, and outcomes. Gagne, Briggs, and Wager (1992) considered the issue from a different point of view, arguing that most instructional design models contain needs analysis, objectives, priorities, resources, and environmental and social elements. Gustafson and Branch (2002) outlined three instructional design model types: product, class, and system. Combining these approaches, instructional design can be defined as a systematic method that (a) covers such stages of the teaching process as analysis, design, development, evaluation, and management; (b) is based on instructional and learning theories; and (c) enhances the quality of teaching (Dick, Carey, \& Carey, 2001; Dooley, 2005; Gustafson \& Branch, 1997; Morrison, Ross, \& Kemp, 2004; Posner \& Rudnitsky, 2001; Smith \& Ragan, 1993, 1999).

Hakkinen (2002) denoted that traditional instructional design models are rooted in behaviorism and that the field of instructional design has been developing since the first models appeared. Instructional design models help illustrate a problem and divide it into manageable parts (Fauser, Henry, \& Norman, 2006). To Hannafin (1993), the shortcomings of traditional instructional design models have become clearer as a result of advancements in instructional technologies. As interest in constructivism has increased because of a paradigm change, instructional design models have become more learner-centered (Crawford, 2004; Edmonds, Branch, \& Mukherjee, 1994). In this regard, most instructional design models aim to explain the key elements of an instructional environment (Hakkinen, 2002).

Most instructional design models are built upon the ADDIE model (Analysis, Design, Development, Implementation, Evaluation) created by the Center for Educational Technology at Florida State University for the U.S. Army (Branson et al., 1975; Dooley, 2005; Hoogveld, Paas, Jochems, \& van Merrienboer, 2002; Strickland, 2006; Şimşek, 2013; Watson, 1981; Zheng \& Smaldino, 2003). To Fer (2009), a performance-oriented, interactive, and innovative mentality is adopted during instruction under the ADDIE model; a systematic process is carried out with learner-centered teaching.

The ARCS (Attention, Relevance, Confidence and Satisfaction) Model of Motivational Design (Keller, 1983, 1987a, 1987b) is widely used for designing, developing, and evaluating motivational strategies, due to its ease of implementation with instructional design processes (Huang \& Johnson, 2002). Each of the four elements plays a critical role in motivating students in the learning process. The development of the ARCS model has been influenced by various learning and instructional theories (Driscoll, 2000). Keller's work was based on social learning and expectancy theories and is popular because it offers strategies that enhance instructional motivation and quality (Bohlin, Milheim, \& Viechnicki, 1993; Main, 1993; Pearson \& Carey, 1995; Small, 2000; Small \& Gluck, 1994). Some researchers have argued that student motivation has a key role in understanding the content being taught (Bigge \& Hunt, 1980; Keller, 1979, 1984; Keller \& Kopp, 1987; Reigeluth, 1987; Small, 2000).

Previous research on instructional design models indicates that basic models such as ADDIE and ARCS continue to be represented in available research. However, the number of studies on instructional design is limited. Rourke and Szabo (2002) revealed that only $10 \%$ of papers published in the Journal of Distance Education between 1996 and 2001 were about instructional design. Gülbahar and Alper (2009) conducted a content analysis of studies carried out in Turkey between 2006 and 2009 and found that only 12 of 149 were about instructional design. Alzand (2010) conducted a study in the Middle East to examine studies between 1998 and 2008 and determined that three instructional design models - Gagne and Briggs (1979), Merrill (2002), and Reigeluth and Stein (1983) — were found to have a positive impact on students' achievement, thinking skills and quality of teaching. Andrew and Goodson (1980) made a comparative analysis of 40 instructional design models and suggested that educators should be careful to assess quality 
levels among the various options. Li (2003) reported that the most used models in designing webbased instruction were ADDIE, Dick and Carey (1978), and Gagne and Briggs (1979), while Royal (2007) indicated that ADDIE, Gagne and Briggs, and Dick and Carey were used most frequently and Khodabandelou and Abu Samah (2012) reported ADDIE, Gagne and Briggs, and Morrison, Ross and Kemp (2004) to be most popular. Finally, Göksu, Özcan, Çakir and Göktas (2014) examined 62 instructional design models implemented in Turkey and found that ADDIE, ARCS, and Dick and Carey were most common.

Studies involving content analysis have been conducted on instructional design models in various countries, but their findings are mostly specific to those regions. Thus, more research is needed to investigate instructional design models with an international framework. Comprehensive, quality research will provide more reliable, generalizable results. Accordingly, this study will examine papers published in SSCI and SCI journals between 1999 and 2014 by investigating the following six research questions:

1. What is the distribution of instructional design models?

2. What is the distribution of studies by year, journal, and country?

3. In the studies on instructional design models,

a. What research methods and designs are widely used?

b. What data collection tools and analysis methods are widely used?

c. What sampling intervals and levels are widely used?

4. What is the distribution of instructional design models by scientific field?

5. What is the distribution of instructional design models by orientation (i.e., productoriented, class-oriented, or system-oriented)?

6. What variables did the studies examine in relation to the instructional design models, and what results did they obtain?

\section{Method}

Content analysis was applied to 113 papers from 44 Social Science Citation Index (SSCI) and Science Citation Index (SCI) journals. Content analysis refers to describing an existing situation and reaching a general judgment by working on a sample taken from an existing large universe (Karasar, 2012). Cohen, Manion, and Morrison (2007) defined content analysis as summarising the contents of accessible resources. Further to this, Büyüköztürk, Kılıç-Çakmak, Akgün, Karadeniz, and Demirel (2012) argued that content analyses synthesise results of studies conducted for a specific purpose or on a specific subject within a common framework. The present study employed content analysis to produce a general evaluation of research trends in instructional design models.

\section{Data collection process}

Data collection began with the identification of SSCI and SCI journals, followed by determining search terms. A search across ScienceDirect, Web of Knowledge, and EBSCOhost revealed 352 studies in 102 journals from 1999 to 2014 containing "model" and "instructional design" in their abstract, title, or keywords. After the researchers had examined these studies individually, those that did not focus on instructional design models were removed. Ultimately, 113 papers from 44 journals were deemed to meet the study criteria; distributions of these papers by journal, index, 
and year are presented in the findings below (and as Supplementary File to this article). Figure 1 summarises the data collection and analysis process which begins with accessing the relevant bibliographic databases and ends with writing to the research questions.

\section{Accessing the databases indexed by $\mathrm{SSCl}$ and $\mathrm{SCl}$ journals}

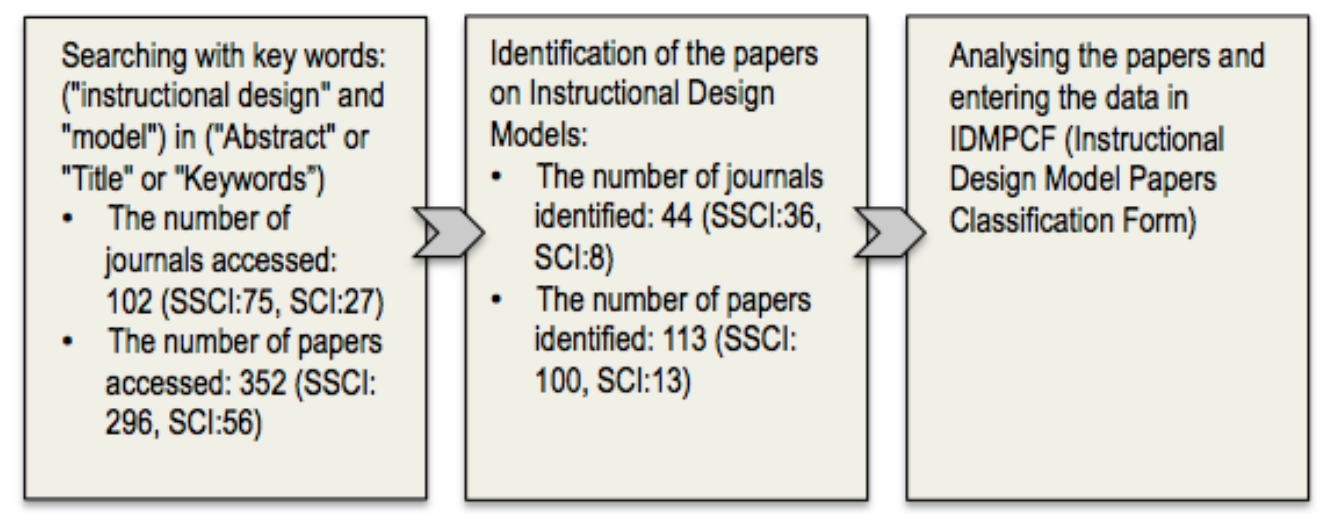

Writing the findings based on the research questions

Figure 1. Research process.

The data obtained from the studies included in the present research were electronically entered into the Instructional Design Model Papers Classification Form (IDMPCF), based on the Educational Technology Papers Classification Form (ETPCF) developed by Göksu, Özcan, Çakir and Göktas (2014). The researchers verified data by checking each entry one at a time, ensuring research validity and reliability. The IDMPCF, which consists of 16 parts, is available as Supplementary Document 1.

\section{Data analysis}

Two doctoral students examined the 113 papers included in the present study. Any uncertainties which emerged during classification of the data and acquisition of the findings were resolved by two faculty members. In this way, an attempt was made to increase data reliability and validity. The descriptive method was applied in the analysis of the data entered into the IDMPCF. Frequency (f) and percentage (\%) tables were formed, and some data were visualised through graphs to see answers to the research questions easily.

\section{Findings}

The order in which the findings of the analyses are presented reflects the research questions addressed in this study. 


\section{Instructional design models}

Table 1 gives the annual distribution of instructional design models used more than once in the 113 papers published in SSCI and SCI journals between 1999 and 2014.

Table 1. Preferred instructional design models (by frequency)

\begin{tabular}{|c|c|c|c|c|c|c|c|c|c|c|c|c|c|c|c|c|c|}
\hline \multirow{2}{*}{ Instructional Design Model } & \multicolumn{17}{|c|}{$1999-2014$} \\
\hline & 99 & 00 & 01 & 02 & 03 & 04 & 05 & 06 & 07 & 08 & 09 & 10 & 11 & 12 & 13 & 14 & $N$ \\
\hline $\begin{array}{l}\text { ADDIE (Florida State University, } \\
\text { 1975; Branson et al., 1975) }\end{array}$ & & & & 1 & & 1 & & 1 & & 2 & 2 & 3 & 1 & 2 & 3 & 4 & 20 \\
\hline ARCS (Keller, 1979) & 1 & & & & 1 & & & 1 & 1 & 1 & 1 & 1 & & 1 & 1 & 1 & 10 \\
\hline Gagne \& Briggs (1979) & & & 2 & 1 & & & & 1 & & 2 & & & & 2 & & 1 & 9 \\
\hline $\begin{array}{l}\text { 4C/ID (van Merrienboer, Clark, \& } \\
\text { de Croock, 2002) }\end{array}$ & & & 2 & 1 & 1 & & 1 & 1 & & & & 1 & & 1 & 1 & & 9 \\
\hline Dick \& Carey (1978) & & 1 & 1 & & & & 1 & & 2 & & 1 & 1 & & 1 & & & 8 \\
\hline Morrison, Ross, \& Kemp (2004) & & 1 & & & & & & & 2 & & 2 & 1 & & & & & 6 \\
\hline 5E Model (Bybee, 1997) & & & & & & & & & & 1 & 1 & 1 & & & 1 & 1 & 5 \\
\hline $\begin{array}{l}\text { Problem-based Learning (PBL) } \\
\text { Model (Barrows, 1985) }\end{array}$ & & & & & & & & & & & & 1 & & 1 & 1 & & 3 \\
\hline $\begin{array}{l}\text { Multiple Cultures (Henderson, } \\
\text { 1996) }\end{array}$ & 1 & & & & & & & & & 1 & & & & & & & 2 \\
\hline $\begin{array}{l}\text { Rapid Prototyping (Tripp \& } \\
\text { Bichelmeyer, 1990) }\end{array}$ & & & & & & & & & & & 1 & & & & 1 & & 2 \\
\hline $\begin{array}{l}\text { Reflexive Model (Richey \& } \\
\text { Nelson, 1996) }\end{array}$ & & & 1 & & 1 & & & & & & & & & & & & 2 \\
\hline $\begin{array}{l}\text { TPACK-based Model (Mishra \& } \\
\text { Koehler, 2006) }\end{array}$ & & & & & & & & & & & & & & & & 2 & 2 \\
\hline Smith \& Ragan (1999) & & & & & & & & 1 & 1 & & & & & & & & 2 \\
\hline Review Studies & & 1 & & 1 & & & 1 & & 1 & & 2 & & & 1 & 1 & 1 & 9 \\
\hline Total & 2 & 3 & 6 & 4 & 3 & 1 & 3 & 5 & 7 & 7 & 10 & 9 & 1 & 9 & 9 & 10 & 89 \\
\hline
\end{tabular}

As seen in Table 1, the most frequently researched/reported model was ADDIE $(n=20,22.47 \%)$, followed by ARCS $(n=10,11.24 \%)$, Gagne and Briggs $(n=9,10.11 \%)$, and 4C-ID $(n=9$, $10.11 \%)$. Some literature review studies $(n=9)$ were included that made a general evaluation of instructional design models. In addition, a further 40 instructional design models were used in a single study, while some studies applied more than one model (see Supplementary Document 2). 


\section{Annual distribution of papers on instructional design}

The majority of papers were published in $2013(n=14)$ and $2014(n=14)$. A further 12 were published in 2010 while 10 were published in 2012, 2009, and 2001. Only two papers were published in 2011, 2004, and 2000. The distribution of papers by year is mapped in Figure 2.

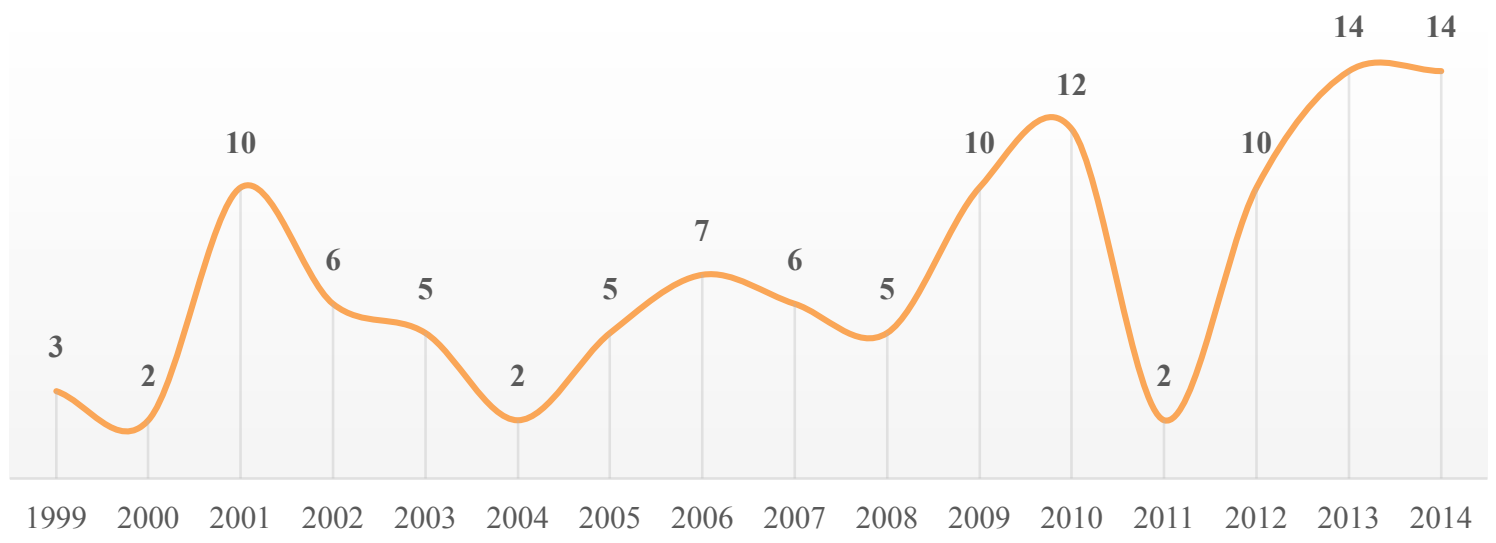

Figure 2. Annual distribution of papers 1999-2014 (by year).

\section{Distribution of papers by journal}

Most ( $n=22,25.88 \%$ ) of the papers on instructional design models were published in ETR\&DEducational Technology Research and Development, followed by Computers \& Education ( $n=14$, $16.47 \%)$, the British Journal of Educational Technology $(n=10,11.76 \%)$, Educational Technology \& Society $(n=6,6.74 \%)$, Computers in Human Behavior $(n=5,5.88 \%)$, and Medical Teacher $(n=5$, $5.88 \%$ ). The Turkey-based Hacettepe University Journal of Education ranked seventh with four papers. Table 2 shows the paper distribution of the 16 journals that published the most papers.

Table 2. Distribution of papers by journal (in descending order of publications)

\begin{tabular}{|c|c|c|c|c|c|c|c|c|c|c|c|c|c|c|c|c|c|c|}
\hline \multirow{2}{*}{ Journal Name } & \multirow{2}{*}{ Index } & \multicolumn{17}{|c|}{$1999-2014$} \\
\hline & & 99 & 00 & 01 & 02 & 03 & 04 & 05 & 06 & 07 & 08 & 09 & 10 & 11 & 12 & 13 & 14 & $N$ \\
\hline $\begin{array}{l}\text { ETR\&D-Educational Technology } \\
\text { Research and Development }\end{array}$ & SSCI & 1 & & 2 & 2 & & 1 & & 2 & 2 & 1 & 3 & & & 1 & 4 & 3 & 22 \\
\hline Computers \& Education & SSCI & & 2 & & & & & 2 & & 1 & & 1 & 3 & & 4 & 1 & & 14 \\
\hline $\begin{array}{l}\text { British Journal of Educational } \\
\text { Technology }\end{array}$ & SSCI & 1 & & & 1 & & 1 & & 1 & 1 & 1 & 1 & 2 & & & 1 & & 10 \\
\hline Educational Technology \& Society & $\mathrm{SSCI}$ & & & 1 & & & & & & & 1 & 1 & 1 & 1 & & & 1 & 6 \\
\hline Computers in Human Behavior & SSCI & & & 2 & & & & & & & 1 & & 1 & & & & 1 & 5 \\
\hline Medical Teacher & SCI & & & & 1 & & & & 1 & & & & & & 2 & 1 & & 5 \\
\hline
\end{tabular}




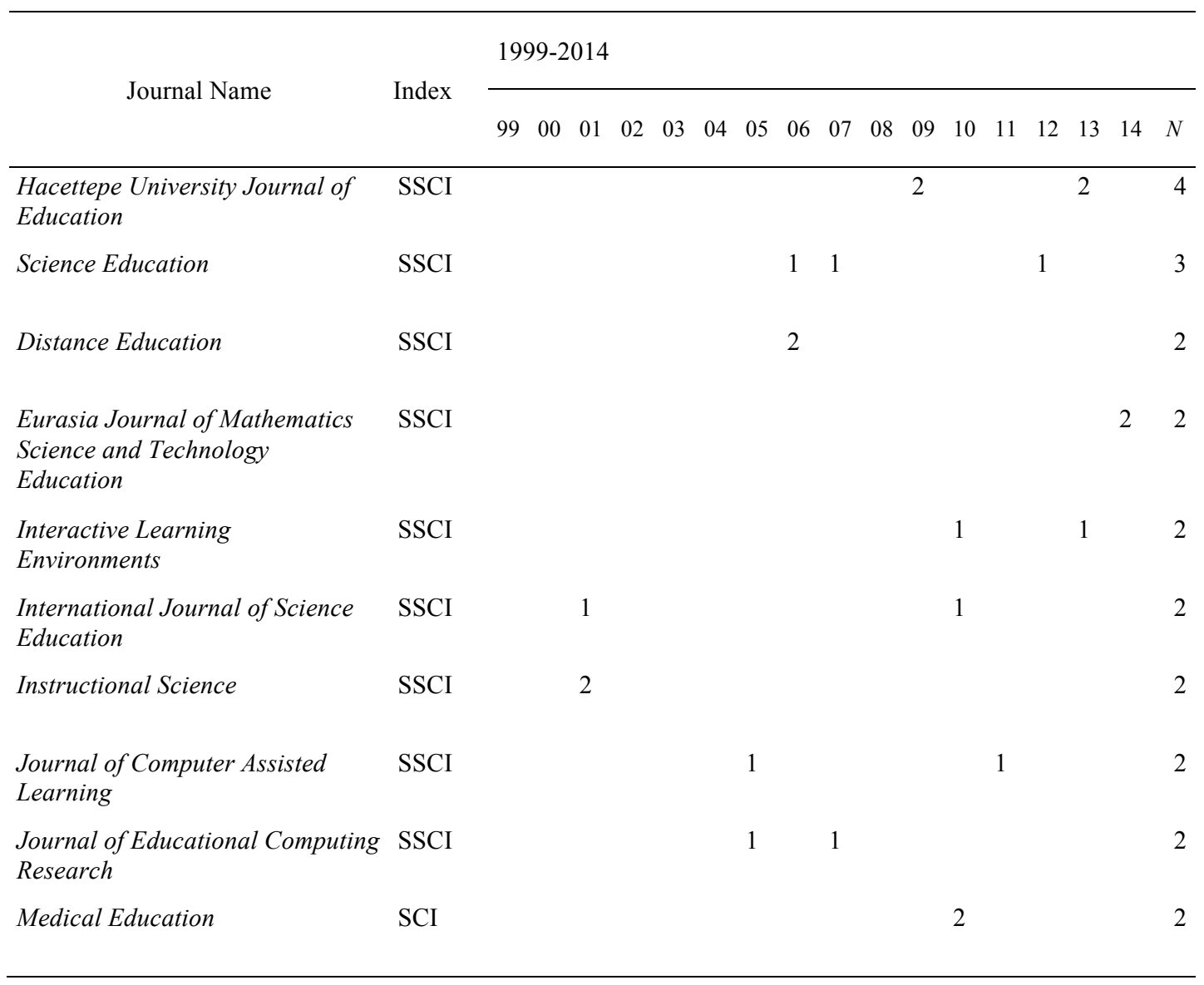

As seen in Table 2, three studies were published in Science Education while each of the following journals published two: Distance Education, Eurasia Journal of Mathematics Science and Technology Education, Interactive Learning Environments, International Journal of Science Education, Instructional Science, Journal of Computer Assisted Learning, Journal of Educational Computing Research, and Medical Education. Each of the other 28 journals published just one study (see Supplementary Document 3).

\section{Countries where studies were carried out}

Among the countries where studies on instructional design models were conducted, the United States ranked first with 50 published papers, followed by the Netherlands (16 papers) and Taiwan (10 papers). Turkey published 8 papers; Australia, 5; and Malaysia, 4. Three studies were conducted in Spain and the United Kingdom, and two were carried out in Canada, Colombia, Cyprus, Finland, Korea, and South Africa. Only one study was conducted in each of the following countries: Bulgaria, Chile, China, Greece, Jamaica, Mexico, Norway, Romania, Sri Lanka, Switzerland, and United Arab Emirates. 


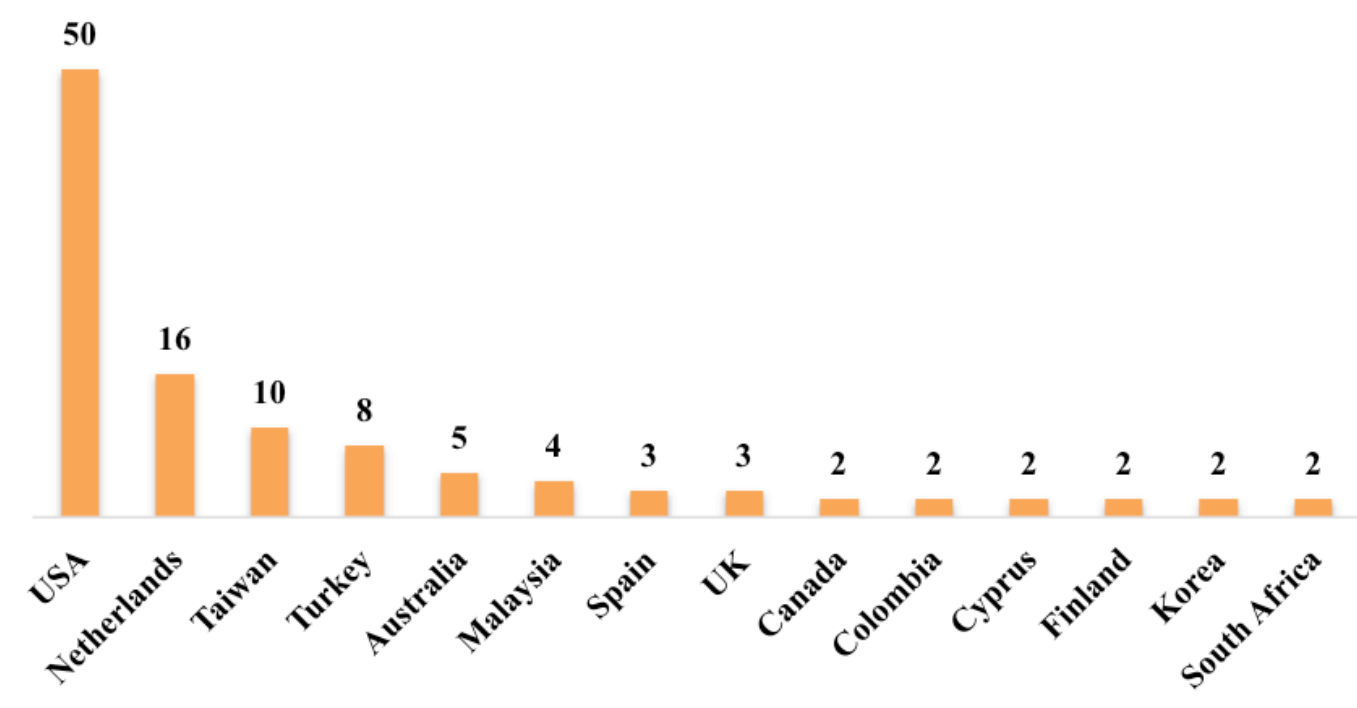

Figure 3. Countries where studies were conducted (in descending order of publication).

\section{Examination of studies by method}

The methods and designs used in the papers are presented in Table 3, which shows qualitative research $(n=45)$ as the most preferred, followed by literature review $(n=28)$, quantitative research $(n=26)$, and mixed research $(n=14)$. Literature review design was mostly used $(n=26)$ in studies employing the literature review method. Meta-analysis design was used in just two studies employing the literature review method.

Table 3. Research methods and designs used in the studies.

\begin{tabular}{llcc}
\hline Research Method & Design & $N(113)$ & $\%$ \\
\hline Qualitative & Case Study & 28 & 39.82 \\
& Grounded Theory & 14 & \\
& Action Research & 3 & 24.78 \\
Literature Review & Literature Review & 26 & 23.01 \\
& Meta-analysis & 2 & 12.39 \\
Quantitative & Experimental & 20 & 6 \\
& Non-experimental & 20 & \\
Mixed & Explanatory (Quantitative $\rightarrow$ Qualitative) & 9 & 2 \\
\hline
\end{tabular}

Experimental design $(n=20)$ was preferred over non-experimental methods $(n=6)$ in quantitative research. Explanatory $(n=9)$ design was used most in studies employing the mixed research method, followed by exploratory $(n=3)$ and triangulation $(n=2)$ designs. Case study $(n=28)$ was used most in qualitative research, followed by grounded theory $(n=14)$ and action research $(n=3)$. No other qualitative design was used in the studies examined. Among the studies using grounded 
theory, 12 proposed new models, while the other two revised existing models. Table 4 presents the studies using grounded theory.

Table 4. Studies using grounded theory

\begin{tabular}{|c|c|c|}
\hline Proposed Model & Models Taken As Basis & Author (Year) \\
\hline Curriculum Reference & ADDIE & Lee \& Kolodner (2011) \\
\hline Hybrid Design & $\begin{array}{l}\text { Dick and Carey; Morrison, Ross, and } \\
\text { Kemp; McManus Model }\end{array}$ & Passerini \& Granger (2000) \\
\hline Living-Systems Design & ADDIE & Plass \& Salisbury (2002) \\
\hline Courseware Development & $\begin{array}{l}\text { ADDIE; Morrison, Ross, and Kemp; } \\
\text { Rapid Prototyping }\end{array}$ & $\begin{array}{l}\text { Durdu, Yalabik, \& Çağıltay, } \\
\text { (2009) }\end{array}$ \\
\hline ELESS & Not specified & Freitas \& Routledge (2013) \\
\hline Eternal, Synergistic Design & ADDIE & Crawford (2004) \\
\hline Integrative & ARCS & Burke \& Moore (2003) \\
\hline Multiple Intelligence Design & $\begin{array}{l}\text { ARCS; Seels and Glasgow; Morrison, } \\
\text { Ross, and Kemp; Smith and Ragan; }\end{array}$ & Tracey \& Richey (2007) \\
\hline RETAIN & ARCS; Gagne and Briggs & $\begin{array}{l}\text { Gunter, Kenny, \& Vick } \\
\text { (2008) }\end{array}$ \\
\hline Six-step ID & $4 \mathrm{C}-\mathrm{ID}$ & $\begin{array}{l}\text { Nadolski, Kirschner, van } \\
\text { Merriënboer, \& Hummel, }\end{array}$ \\
\hline WisCom & Not specified & Gunawardena et al. (2006) \\
\hline New Model Proposed & Gagne and Briggs; Smith and Ragan & Cronjé (2006) \\
\hline Existing Model Revised & Appreciative Instructional Design & Norum (2000) \\
\hline Existing Model Revised & Virtual Reality Model & Chen \& The (2013) \\
\hline
\end{tabular}

\section{Data collection tools and analysis methods}

Figure 4 presents the data collection tools used in the papers examined and indicates that the tools most preferred were: interview $(n=36)$; questionnaire $(n=30)$; achievement test $(n=14)$; attitude/perception/personality/interest/aptitude tests $(n=13)$; observation $(n=7)$; and logs $(n=5)$. 


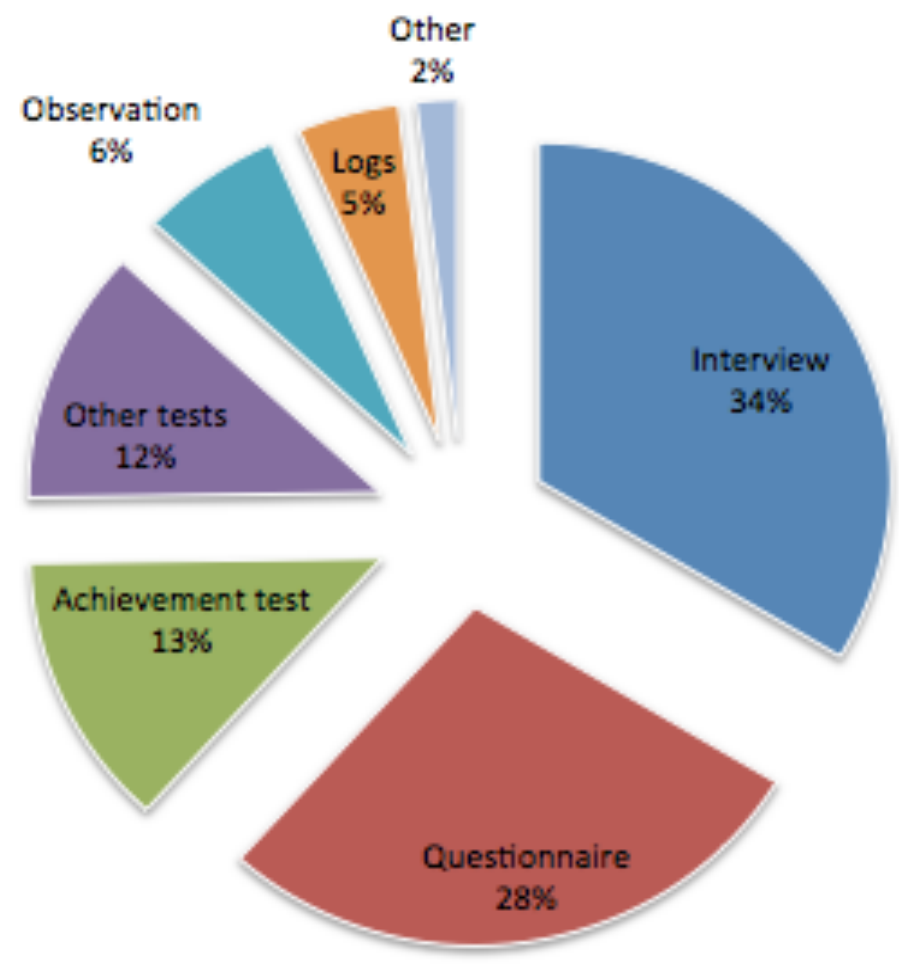

Figure 4. Distribution of the data collection tools used in the papers.

Table 5 presents the data analysis methods and techniques used in the studies.

Table 5. Distribution of data analysis methods and techniques used in the studies

\begin{tabular}{llcc}
\hline \multicolumn{1}{c}{ Data Analysis Method } & \multicolumn{1}{c}{ Data Analysis Technique } & $N(63)$ & $\%$ \\
\hline Quantitative & Predictive & 24 & 57.14 \\
& Descriptive & 12 & 42.86 \\
Qualitative & Descriptive Analysis & 20 & 6 \\
& Content Analysis & & \\
& Document Analysis & 1 & \\
\hline
\end{tabular}

Table 5 indicates that quantitative analysis $(n=36)$ was more preferred than qualitative analysis $(n=27)$. Among quantitative data analysis techniques, predictive analysis $(n=24)$ was used more frequently than descriptive analysis $(n=12)$. Among qualitative data analysis techniques, descriptive analysis $(n=20)$ was most preferred, followed by content analysis $(n=6)$. Document analysis $(n=1)$ was the least preferred qualitative data analysis technique. 


\section{Sampling intervals and levels}

Findings are given in Table 6, which shows the most preferred interval as 11 to 30 participants $(\mathrm{n}=22)$, followed by 101 to $300(n=21), 31$ to $100(n=18), 1$ to $10(n=6)$, and 301 to $1000(n=4)$. One study included over 1000 participants while three studies did not specify sampling intervals.

Table 6. Sampling intervals used in the studies

\begin{tabular}{|c|c|c|}
\hline Sampling Size & $N(75)$ & $\%$ \\
\hline $11-30$ & 22 & 29.33 \\
\hline $101-300$ & 21 & 28.00 \\
\hline $31-100$ & 18 & 24.00 \\
\hline $1-10$ & 6 & 8.00 \\
\hline $301-1000$ & 4 & 5.33 \\
\hline$>1000$ & 1 & 1.33 \\
\hline Not specified & 3 & 4.00 \\
\hline
\end{tabular}

Table 7 presents sampling levels, including various learning levels and professions.

Table 7. Sampling levels used in the studies

\begin{tabular}{lcc}
\hline \multicolumn{1}{c}{ Sampling Level } & $N(75)$ & $\%$ \\
\hline Undergraduate Student & 22 & 29.33 \\
Instructional Designer & 9 & 12.00 \\
High School Student & 7 & 9.33 \\
Teacher & 7 & 9.33 \\
Post-graduate Student & 6 & 8.00 \\
Faculty Members & 5 & 6.67 \\
Middle School Student & 5 & 6.67 \\
Primary School Student & 4 & 5.33 \\
Administrator & 2 & 2.67 \\
Nurse & 2 & 2.67 \\
Doctor & 1 & 1.33 \\
Attorney & 1 & 1.33 \\
Other & 4 & 5.33 \\
\hline
\end{tabular}

The sampling level preferred most in studies on instructional design models was undergraduate students $(n=22)$, followed by instructional designers $(n=9)$, high school students $(n=7)$, teachers $(n=7)$, and post-graduate students $(n=6)$. Less common samples were faculty members $(n=5)$, middle school students $(n=5)$, primary school students $(n=4)$, administrators $(n=2)$, and nurses $(n=2)$. Doctors were the research participants of just one study, as were attorneys.

\section{Scientific fields in which studies were conducted}

Table 8 presents the distribution of studies investigating the influences of instructional design models on different elements by scientific field. 
Journal of Learning Design

Göksu, Özcan, Cakir \& Göktas

Table 8. Distribution of studies by scientific field

\begin{tabular}{lcc}
\hline \multicolumn{1}{c}{ Scientific Fields } & $N(64)$ & $\%$ \\
\hline Computer and Instructional Technologies & 16 & 25.00 \\
Science Education & 11 & 17.19 \\
Engineering Sciences & 8 & 12.50 \\
Social Sciences & 7 & 10.94 \\
Educational Sciences & 6 & 9.38 \\
Medicine & 5 & 7.81 \\
Mathematics & 3 & 4.69 \\
Linguistic Sciences & 2 & 3.13 \\
Not Specified & 2 & 3.13 \\
Other & 4 & 6.25 \\
\hline
\end{tabular}

Table 8 shows that the models were mostly implemented in Computer and Instructional Technologies $(n=16)$, followed by Science Education $(n=11)$ and Engineering Sciences $(n=8)$. Seven studies were carried out in Social Sciences, six in Educational Sciences, five in Medicine, three in Mathematics, and two in Linguistic Sciences.

\section{Instructional design models used in the studies}

Figure 5 presents the findings concerning the orientation of the instructional design models used in the papers examined (i.e., system-oriented, class-oriented, and product-oriented). The studies were mostly on system-oriented models $(n=76,59.84 \%)$, followed by class-oriented $(n=39,30.71 \%)$ and product-oriented $(n=12,9.45 \%)$ models.

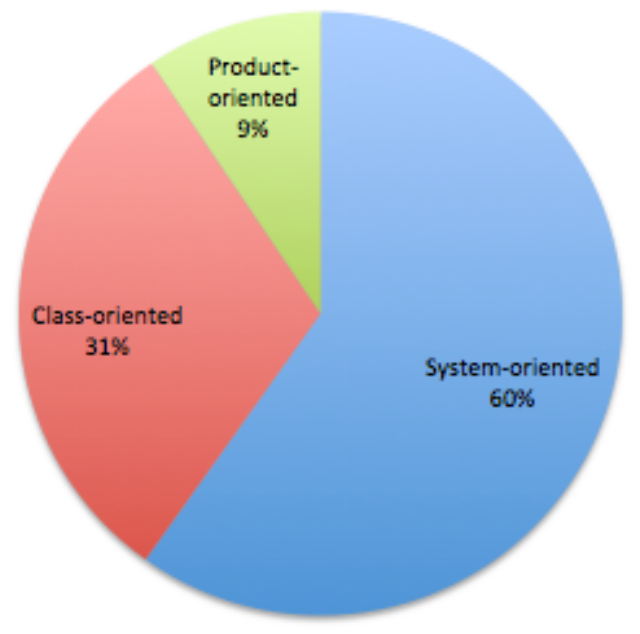

Figure 5. Types of the instructional design models.

\section{Study variables}

Table 9 presents findings concerning the variables discussed in the papers examined and the results obtained through the investigation of these variables. 
Table 9. Study variables and the influences of the models on those variables

\begin{tabular}{|c|c|c|c|c|c|c|c|c|c|c|c|c|c|c|c|}
\hline \multirow[b]{2}{*}{$\begin{array}{l}\text { INSTRUCTIONAL DESIGN } \\
\text { MODELS }\end{array}$} & \multicolumn{15}{|c|}{ VARIABLES EXAMINED } \\
\hline & 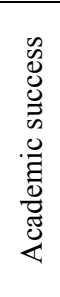 & 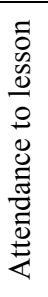 & 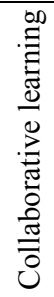 & 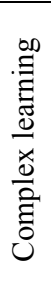 & 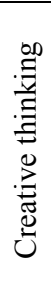 & 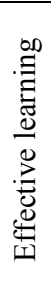 & 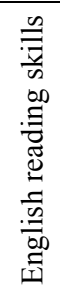 & $\bar{\Xi}$ & 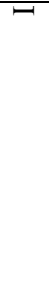 & $\sum^{\pi}$ & 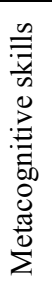 & 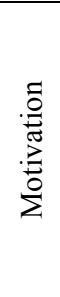 & 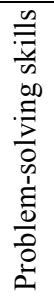 & 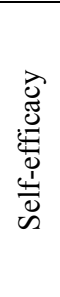 & $\begin{array}{l}\frac{n}{\bar{g}} \\
\frac{\pi}{\omega} \\
\frac{\pi}{0} \\
\dot{0}\end{array}$ \\
\hline ADDIE & $\oplus$ & - & $\oplus$ & - & $\oplus$ & $\oplus$ & - & - & - & - & - & $\oplus$ & - & - & - \\
\hline ARCS & - & - & - & - & - & - & $\oplus$ & - & $\oplus$ & - & - & $\oplus$ & - & - & - \\
\hline Case-based Reasoning ID Model & - & - & - & - & - & - & - & - & - & - & - & $\oplus$ & - & - & - \\
\hline Cognitive Load Theory & - & - & - & $\oplus$ & - & - & - & - & - & - & - & & - & - & - \\
\hline Collaborative Design Model & - & - & - & - & - & - & - & - & - & - & - & $\oplus$ & - & - & - \\
\hline Constructivist Learning Environment & - & - & - & - & - & - & - & - & - & - & - & & $\oplus$ & - & - \\
\hline Continuum of Knowledge & - & - & - & - & - & - & $\oplus$ & - & - & - & $\oplus$ & & - & - & - \\
\hline Dick and Carey & - & - & $\oplus$ & - & - & - & - & $\oplus$ & - & - & - & $\oplus$ & - & - & - \\
\hline Differentiated ID Model & - & - & - & - & - & - & - & - & - & $\oplus$ & $\oplus$ & & - & $\oplus$ & - \\
\hline Gagne and Briggs & - & - & $\oplus$ & - & - & $\oplus$ & - & $\oplus$ & - & - & - & $\oplus$ & - & - & - \\
\hline IDEAS Model & - & - & - & - & - & - & - & - & - & - & - & $\oplus$ & - & - & - \\
\hline Laurillard's Model & - & - & - & $\oplus$ & - & - & - & - & - & - & - & - & - & - & - \\
\hline Morrison, Ross, and Kemp & - & - & - & - & - & - & - & - & $\oplus$ & $\oplus$ & - & $\oplus$ & - & - & - \\
\hline PBL Model & $\oplus$ & - & - & - & - & - & - & - & - & - & - & & - & - & - \\
\hline Reflexive Model & - & $\oplus$ & - & - & - & - & - & - & - & - & - & & $\oplus$ & - & - \\
\hline Rapid Prototyping & - & - & - & - & - & - & - & - & - & - & - & $\oplus$ & - & - & - \\
\hline RTI Model & - & - & - & - & - & - & - & - & $\oplus$ & - & - & & - & - & - \\
\hline TUM Model & - & ๑ & - & - & - & - & - & - & $\oplus$ & - & - & & - & - & - \\
\hline WisCom Model & - & - & $\oplus$ & - & - & - & - & ๑ & - & - & - & & - & - & - \\
\hline 3D Model & - & - & - & - & - & - & - & - & $\oplus$ & - & - & & - & - & - \\
\hline 3C3R Model & - & - & - & - & - & - & - & - & $\oplus$ & - & - & & - & - & - \\
\hline 4C-ID & - & - & - & - & - & - & - & - & - & - & - & & $\oplus$ & - & - \\
\hline 5E Model & $\oplus$ & - & - & - & $\oplus$ & - & - & - & - & $\oplus$ & - & $\oplus$ & - & - & $\oplus$ \\
\hline
\end{tabular}

In summary, it can be noted that:

- $\quad$ ADDIE, the PBL Model, and the 5E Model were shown to improve academic success;

- Dick and Carey, Gagne and Briggs, and the WisCom Model were shown to improve individual learning;

- Cognitive Load Theory and Laurillard's Model were shown to improve complex learning;

- ADDIE and Gagne and Briggs were shown to improve effective learning;

- $\quad$ ADDIE, Dick and Carey, Gagne and Briggs, and the WisCom Model were shown to improve collaborative learning;

- The Continuum of Knowledge and the Differentiated ID Model were shown to improve 
metacognitive skills;

- $\quad$ TUM and the Reflexive Model were shown to increase attendance to lesson;

- $\quad$ ARCS and the Continuum of Knowledge were shown to improve English reading skills;

- The Differentiated ID Model, Morrison, Ross, and Kemp, and the 5E Model were shown to improve mathematical skills;

- The Differentiated ID Model was shown to improve self-efficacy;

- The Constructivist Learning Environment, the Reflexive Model, and 4C-ID were shown to improve problem-solving skills;

- The 5E Model was shown to improve social skills;

- ADDIE, ARCS, the Case-based Reasoning ID Model, the Collaborative Design Model, Dick and Carey, Gagne and Briggs, the IDEAS Model, Morrison, Ross, and Kemp, Rapid Prototyping, and the 5E Model were shown to increase motivation;

- $\mathrm{ADDIE}$ and the 5E Model were shown to improve creative thinking; and

- $\quad$ ARCS, Morrison, Ross and Kemp, the RTI Model, TUM, the 3D Model, and the 3C3R Model were shown to improve learning rate (efficacy).

Findings were also obtained that could not be summarised in Table 9. These are:

- A study focusing on the 3D Model concluded that it reduced cognitive load (Boot, Nelson, van Merrienboer, \& Gibbons, 2007).

- $\quad$ Another study revealed that the 7E Model contributed to conceptual change and knowledge permanence (Demirezen \& Yağbasan, 2013).

- Three studies applying the 4C-ID Model determined that it supported teachers in designing learning tasks (Hoogveld et al., 2002); that product-oriented practices were more effective for teacher training in comparison to process-oriented practices (Hoogveld, Paas, \& Jochems, 2005); and that instructional design should be applied in medical training (Levinson, 2010).

- Another study applied the PBL Model and emphasised the importance of instructional design in globalizing modern medical training (Stevens \& Goulbourne, 2012).

- Craft, Feldon, and Brown (2014) concluded from their study on medicine that the GEL model was more efficient than ELT in simulation-based learning.

- Shambaugh and Magliaro (2001) found that the systematic features of the Reflexive Model made students attach particular importance to learning.

- Visscher-Voerman and Gustafson (2004) concluded that ADDIE facilitated the design of effective learning experiences while Güler, Kılıç, and Çavuş (2014) suggested that mobile learning based on teaching design would be more effective and that ADDIE would make mobile learning both more effective and more productive.

- Some studies revealed the effectiveness of ARCS applied in Matlab training (Huang, 
Huang, Diefes-Dux, \& Imbrie, 2006) and the effectiveness of the Content-based ID Model in virtual learning environment designs (Laverde, Cifuentes, \& Rodriguez, 2007).

- Angeli and Valanides (2005) took Dick and Carey's model as a basis and mentioned the importance of integrating technology into the teacher training curriculum. Lee and Kim (2014) conducted a study using the TPACK-based ID Model with preservice teachers, also studying technology integration.

- In another study, the same model was found to improve technology integration and students' geographical questioning skills (Doering, Koseoglu, Scharber, Henrickson, \& Lanegran 2014).

- A study employing Dick and Carey, Morrison, Ross, and Kemp, and the Collaborative Design Model highlighted that motivation and results processing should be taken into account when designing digital game-based learning (Huang, Huang, \& Tschopp, 2010).

- Woo (2014) concluded in his similar ARCS-based study that it was necessary to increase the motivation and germane cognitive loads of digital game-based learning designers to improve their processes.

- Meanwhile, Freitas and Routledge (2013) developed the ELESS model for evaluating educational games.

- Another study revealed Jonassen's Constructivist Learning Environment Model as effective in improving students' unstructured problem-solving skills (Choi \& Lee, 2009).

- In addition, it was reported that the Multiple Cultures Model can provide culturally sensitive and appropriate online education if students' socio-cultural backgrounds and learning styles are known and a suitable instructional paradigm is applied (McLoughlin, 1999). This model provides a structure that improves the design process through the integration of culture-based design features (Young, 2008).

- A study employing the Living-Systems Approach Model indicated that this model not only allows individuals to regulate the learning process but indeed grows and changes in order to accommodate their needs (Plass \& Salisbury, 2002).

- $\quad$ Meyen, Aust, Bui, Ramp, and Smith (2002) concluded that online instructional designs should be developed in coordination with product systems.

- Chang and Chen (2014) concluded in their study based on the Kirkpatrick model that it was effective in developing lifelong learning and digital learning at universities and that it improved students' attitudes and research abilities.

- Finally, Lin et al. (2014) concluded that the 5E model was effective in improving educational materials and attitudes in science education.

\section{Discussion and conclusion}

This study analysed 113 papers on instructional design models published in 44 SSCI and SCI journals in terms of: models used; distribution by year, journal, and country; methods applied; scientific fields in which studies were conducted; orientation of models used; variables examined; and results obtained. The ADDIE model was the most preferred, followed by ARCS, Gagne and Briggs, 4C-ID, Dick and Carey, Morrison, Ross, and Kemp, the 5E Model, the Problem-based Learning (PBL) Model, the Multiple Cultures ID Model, Rapid Prototyping, the Reflexive Model, 
the TPACK-based ID Model, and Smith and Ragan, respectively. Across the examined papers, 53 models were used. Besides the models above, a further 40 instructional design models were used in a single study. Consistent with the results of the present study, others (see, for example, Khodabandelou \& Abu Samah, 2012; Li, 2003; Royal, 2007) found that ADDIE, Dick and Carey, Gagne and Briggs, Morrison, Ross and Kemp, and Reigeluth's Elaboration Model to be the most preferred models. However, it is noteworthy that ARCS was not generally preferred in these studies. This may be because researchers working on educational technologies in recent years have emphasised motivation in learning. Further to this, Göksu, Özcan, Çakir and Göktas (2014) carried out a content analysis to examine studies on instructional design models conducted in Turkey and concluded that the most preferred models were: ADDIE; ARCS; Dick and Carey; Gagne and Briggs; ASSURE; 5E Model; and, Morrison, Ross, and Kemp. The present study found no studies employing ASSURE in the journals it reviewed. The inclusion of 5E and Problem-based Learning (PBL) Models, which take the constructivist learning approach as a basis, shows how instructional design models vary over time based on current learning approaches.

Most papers of those reviewed were published in 2013 and 2014. In the last six years of the examined period, 62 studies were conducted on instructional design models. However, only 51 papers were published in all ten years from 1999 to 2008. Instructional design models have increased recently as a result of the importance attached to systematising teaching and enhancing quality. In addition, as journals are now published online and electronic databases have been developed, a wider variety of studies can be accessed more easily. As to the journals in which the papers were published, the greatest number was published in ETR\&D, followed by Computers \& Education and British Journal of Educational Technology. SSCI journals published 100 papers, while SCI journals published 13. Lee and Jang (2014) analysed 20 papers implementing or evaluating instructional design models and similarly discovered that most of these papers were published in ETR\&D and British Journal of Educational Technology. Researchers may prefer ETR\&D, Computers \& Education, and British Journal of Educational Technology because these journals focus on studies on instructional design.

The greatest number of studies on instructional design models were conducted in the United States, followed by the Netherlands, Taiwan, and Turkey. The number of journals published in these countries may explain this finding. In addition, as to Turkey being near the top, local departments of computer and instructional technologies started to produce graduates in 2002 (see, for example, Göksu, Özcan, Çakir \& Göktas, 2014), so research in this field has increased.

Qualitative research methods were preferred in the studies examined, followed by literature review, quantitative methods, and mixed methods. The qualitative methods used were: case study $(n=28)$; grounded theory $(n=14)$; and, action research $(n=3)$. Fourteen new models were proposed in studies using grounded study design mostly based on ADDIE, ARCS, Morrison, Ross, and Kemp, Dick and Carey, or Smith and Ragan. Two models were revised in two different studies employing grounded theory design. Among 28 reviewed studies, only two were carried out through meta-analysis, and experimental design was used most in quantitative studies.

The top three data collection tools used in the studies examined were: interviews, questionnaires, and achievement tests. As to data analysis, quantitative methods were used more frequently than qualitative. Predictive analysis was the most preferred quantitative data analysis technique while descriptive analysis was the most preferred qualitative data analysis technique. Among qualitative analysis, content analysis was applied six times, while document analysis was used only once. Clearly, the reviewed sample indicates that there is a deficiency in content and document analyses on instructional design models.

The most preferred sampling interval was 11 to 30 participants, and most participants consisted of undergraduate students, who are easily accessible to researchers. Other popular sampling levels included instructional designers, high school students, teachers, and post-graduate students.

The studies examined were mostly conducted in the fields of computer and instructional 
technologies, science education, engineering sciences, and social sciences. Previously, Göksu, Özcan, Çakir and Göktas (2014) had similarly revealed that studies on instructional design models were mostly carried out in the fields of computer and instructional technologies, science, and mathematics. These findings are not surprising because one of the reasons for the emergence of instructional design models is the need for new learning and teaching methods as a result of advancing instructional technologies. Not many studies were conducted in the field of medicine, though Levinson (2010) has stated that instructional design should be applied in medical training. Furthermore, Stevens and Goulbourne (2012) conducted a study using the PBL Model and highlighted the importance of instructional design in globalising today's medical training. Hsu, Lee-Hsieh, Turton and Cheng (2014) stressed the use of the ADDIE model in their study on medicine which they promoted as guidance for administrative changes.

The majority of the 53 different models used in the studies examined were system-oriented while only a few were product-oriented. The model types of the study were determined based on the literature (Fauser et al., 2006; Gustafson \& Branch, 2002). However, a new classification is needed because a number of recently developed models could not be included under the umbrella of existing models.

Motivation, collaborative learning, learning rate (efficacy), individual learning, effective learning, and problem-solving skills were the variables on which the examined models had the highest influence, which was generally positive. This paper has pointed out how the influences of some models have not been investigated. The instructional design models used in the studies examined guided the use of instructional materials and methods in some experimental studies. Some studies made partial use of models while others attempted to reveal influences on differing variables. Others proposed new models or revised existing models. The models were referred to in the studies as instructional design models, learning models, instructional models, motivation models, design models, or design theories. This variety represents how some models function as an instructional method or theory besides being an instructional design model. These concepts are intertwined in the literature.

The following eight recommendations are based on the findings discussed in this paper:

1. SSCI or SCI journals mostly feature studies focusing on basic models. Thus, research must discuss the effectiveness of new models, which may reveal the cause of their limited frameworks.

2. Samples containing participants from different levels could be formed in research on instructional design models.

3. Studies employing content analysis and meta-analysis could be conducted on instructional design models.

4. The number of studies on instructional design models in medicine, linguistic sciences, and social sciences could be increased to reveal their influences.

5. More research may uncover the influences of instructional design models on attendance to lesson, academic success, social skills, metacognitive skills, and creative thinking.

6. Influences of some models on some variables were not investigated (see Table 9). Research may clarify these unknown influences.

7. A study investigating and evaluating recently developed models using the classification of Gustafson and Branch (2002) may increase their usefulness and functionality.

8. The definitions of instructional design terms such as instructional design model, learning model, instructional model, motivational model, design model, and design theory may 
need to be reconsidered and clarified.

It is clear that there is considerable nuance in definitions of instructional design with a number of extant models being added to with new and revised models. All, however, share the common goal of categorising and assisting teaching and learning.

\section{References $^{1}$}

Aamodt, A., \& Plaza, E. (1994). Case-based reasoning: Foundational issues, methodological variations, and system approaches. AI Communications, 7(1), 39-59.

Alzand, W. (2010). Instruction design and educational quality. Procedia Social and Behavioral Sciences, 2(2010), 4074-4081.

Andrews, D. H., \& Goodson, L. A. (1980). A comparative analysis of models of instructional design. Journal of Instructional Development, 3(4), 2-16.

Angeli, C., \& Valanides, N. (2005). Preservice elementary teachers as information and communication technology designers: an instructional systems design model based on an expanded view of pedagogical content knowledge. Journal of Computer Assisted Learning, 21, 292-302.

Barrows, H. S. (1985). How to design a problem-based curriculum for the preclinical years. New York: Springer.

Bereiter, C., \& Scardamalia, M. (1987). The psychology of written composition. Hillsdale, NJ: Erlbaum.

Bigge, M. L., \& Hunt, M. P. (1980). Psychological foundations of education: An introduction to human motivation, development, and learning. New York: Harper \& Row.

Black, J. B., \& McClintock, R. O. (1996). An interpretation construction approach to constructivist design. In B. Wilson (Ed.), Constructivist Learning Environments (pp. 25-31). Englewood Cliffs, NJ: Educational Technology Publications.

Bohlin, R. M., Milheim, W. D., \& Viechnicki, K. J. (1993). The development of a model for the design of motivational adult instruction in higher education. Journal of Educational Technology Systems, 22(1), 3-17.

Boot, E. W. (2005). Building-block solutions for developing instructional software (Unpublished doctoral dissertation). Open Universiteit Nederland, Heerlen. Retrieved from http://www.ou.nl/Docs/Expertise/OTEC/Publicaties/ Eddybootproefschrift\%20for\%20web\%200.2.pdf

Boot, E. W., Nelson, J., Merrienboer, J. J. G., \& Gibbons, A. S. (2007). Stratification, elaboration and formalisation of design documents: Effects on the production of instructional materials. British Journal of Educational Technology, 38(5), 917-933.

Bransford, J. D., Brown, A. L., \& Cocking, R. R. (2000). How people learn. Washington, DC: National Academy Press.

Branson, R. K. (1978). Handbook of procedures for instructional systems development. Educational Technology, 18(3), 11-14.

Branson, R. K., Rayner, G. T., Cox, J. L., Furman, J. P., King, F. J., \& Hannum, W. H. (1975). Interservice procedures for instructional systems development (TRADOC Pam 350-30 NAVEDTRA 106A). Ft. Monroe, VA: U.S. Army Training and Doctrine Command.

\footnotetext{
${ }^{1}$ References include citations in the Supplementary Documents 1-3.
} 
Brinton, D. M., Snow, M. A., \& Wesche, M. B. (1989). Content-based second language instruction. New York: Newbury House.

Burke, L. A., \& Moore, J. E. (2003). A perennial dilemma in OB education: Engaging the traditional student. Academy of Management Learning and Education, 2(1), 37-52.

Büyüköztürk, Ş., Kılıç-Çakmak, E., Akgün, Ö. E., Karadeniz, Ş., \& Demirel, F. (2012). Scientific research methods. Ankara, Turkey: Pegem Academy.

Bybee, R. W. (1997). Achieving scientific literacy. Portsmouth, NH: Heinemann.

Chang, N., \& Chen, L. (2014). Evaluating the learning effectiveness of an online information literacy class based on the Kirkpatrick framework. Libri, 64(3), 211-223.

Chen, C. J., \& Teh, C. S. (2013). Enhancing an instructional design model for virtual reality-based learning. Australasian Journal of Educational Technology, 29(5), 699-716. Retrieved from https://ajet.org.au/index.php/AJET/article/download/247/758

Chen, C. J., Toh, S. C., \& Wan, M. F. (2004). The theoretical framework for designing desktop virtual reality-based learning environments. Journal of Interactive Learning Research, 15(2), $147-167$.

Choi, I., \& Lee, K. (2009). Designing and implementing a case-based learning environment for enhancing ill-structured problem solving: Classroom management problems for prospective teachers. Educational Technology Research and Development, 57, 99-129.

Clark, R. E. (2004). Design document for a guided experiential learning course. Final report on contract DAAD 19-99-D-0046-0004 from TRADOC to the Institute for Creative Technology and the Rossier School of Education at the University of Southern California. Retrieved from http://www.cogtech.usc.edu/publications/clark_gel.pdf

Clinton, G. (2007). Creativity and design: A study of the learning experience of instructional design and development graduate students (Unpublished doctoral dissertation). University of Georgia, Athens.

Cohen, L., Manion, L., \& Morrison, K. (2007). Research methods in education. New York: Routledge.

Craft, C., Feldon, D. F., \& Brown, E. A. (2014). Instructional design affects the efficacy of simulation-based training in central venous catheterization. The American Journal of Surgery, 207(5), 782-789.

Crawford, C. (2004). Non-linear instructional design model: Eternal, synergistic design and development. British Journal of Educational Technology, 35(4), 413-420.

Cronjé, J. (2006). Paradigms regained: Toward integrating objectivism and constructivism in instructional design and the learning sciences. Educational Technology Research and Development, 54(4), 387-416.

Demirezen, S., \& Yağbasan, R. (2013). The effect of 7E Model on misconceptions about simple electrical circuits. Hacettepe University Journal of Education, 28(2), 132-151.

Dick, W., \& Carey, L. (1978). The systematic design of instruction (1st ed.). New York: HarperCollins.

Dick, W., Carey, L., \& Carey, J. O. (2001). The systematic design of instruction. New York: HarperCollins.

Doering, A., Koseoglu, S., Scharber, C., Henrickson, J., \& Lanegran, D. (2014). Technology integration in $\mathrm{K}-12$ geography education using TPACK as a conceptual model. Journal of Geography, 113(6), 223-237.

Dondlinger, M. (2007a). Measuring presence in online learning environments. In C. Crawford, D. Willis, R. Carlsen, I. Gibson, K. McFerrin, J. Price, et al. (Eds.), Proceedings of the Society for 
Information Technology and Teacher Education International Conference 2007 (pp. 291-296). Chesapeake, VA: AACE.

Dondlinger, M. (2007b). Technology based learning environments and student satisfaction. In C. Crawford, D. Willis, R. Carlsen, I. Gibson, K. McFerrin, J. Price, et al. (Eds.), Proceedings of the Society for Information Technology and Teacher Education International Conference 2007 (pp. 297-301). Chesapeake, VA: AACE.

Dooley, K. E. (2005). Advanced methods in distance education: Applications and practices for educators, administrators and learners. Hershey, PA: Information Science Publishing.

Driscoll, M. P. (2000). Introduction to theories of learning and instruction (2nd ed.). In M. P. Driscoll (Ed.), Psychology of learning for instruction (pp. 3-28). Boston, MA: Allyn \& Bacon.

Durdu, P. O., Yalabik, N., \& Cagiltay, K. (2009). A distributed online curriculum and courseware development model. Educational Technology \& Society, 12(1), 230-248.

Edmonds, G. S., Branch, R. C., \& Mukherjee, P. (1994). A conceptual framework for comparing instructional design models. Education Technology Research and Development, 4, 55-72.

Eisenkraft, A. (2003). Expanding the 5E Model. The Science Teacher, 70(6), 56-59.

Fauser, M., Henry, K., \& Norman, D. K. (2006). Comparison of alternative instructional design models. University of Central Florida. Retrieved from https://deekayen.net/ comparison-alternative-instructional-design-models

Fer, S. (2009). Social constructivism and social constructivist curricula in Turkey for the needs of differences of young people: Overview in light of the PROMISE project. In T. Tajmel \& S. Klaus (Eds.), Science education unlimited: Approaches to equal opportunity in learning science (pp. 179-199). Munster, Germany: Waxmann Verlag.

Freitas, S., \& Routledge, H. (2013). Designing leadership and soft skills in educational games: The e-leadership and soft skills educational games design model (ELESS). British Journal of Educational Technology, 44(6), 951-968.

Fuchs, L. S., \& Fuchs, D. (1998). Treatment validity: A unifying concept for reconceptualizing the identification of learning disabilities. Learning Disabilities Research and Practice, 13, $204-$ 219.

Gagne, R. M., \& Briggs, L. (1979). Principles of instructional design (2nd ed.). Fort Worth, TX: Harcourt Brace Jovanovich.

Gagne, R. M., Briggs, L. J., \& Wager, W. W. (1992). Principles of instructional design. Philadelphia, PA: Harcourt Brace Jovanovich.

Gentry, C. G. (1994). Introduction to instructional development: Process and technique. Belmont, CA: Wadsworth Publishing Company.

Göksu, I., Özcan, K.V., Çakir, R. \& Göktas, Y. (2014). Studies related to instructional design models in Turkey. Elementary Education Online, 13(2), 694-709.

Greer, M. (1992). ID project management: Tools and techniques for instructional designers and developers. Englewood Cliffs, NJ: Educational Technology.

Gülbahar, Y., \& Alper, A. (2009). A content analysis of the studies in instructional technologies area. Ankara University, Journal of Faculty of Educational Sciences, 42(2), 93-111.

Güler, Ç., Kılıç, E., \& Çavuş, H. (2014). A comparison of difficulties in instructional design processes: Mobile vs. desktop. Computers in Human Behavior, 39(2014) 128-135.

Gunawardena, C. N., Ortegano-Layne, L., Carabajal, K., Frechette, C., Lindemann, K., \& Jennings, B. (2006). New model, new strategies: Instructional design for building online wisdom communities. Distance Education, 27(2), 217-232.

Gunckel, K. L., Bae, M., \& Smith, E. L. (2007). Using instructional models to promote effective use of curriculum materials among preservice elementary teachers. Paper presented at the 
annual meeting of the National Association of Research in Science Teaching, New Orleans, LA.

Gunter, G. A., Kenny, R. F., \& Vick, E. H. (2008). Taking educational games seriously: Using the RETAIN model to design endogenous fantasy into standalone educational games. Educational Technology Research and Development, 56(5), 511-537.

Gustafson, K. L., \& Branch, R. M. (1997). Revisioning models of instructional development. Educational Technology Research and Development, 45(3), 73-89.

Gustafson, K. L., \& Branch, R. M. (2002). Survey of instructional development models (4th ed.). Syracuse, NY: ERIC Clearing House on Information Technology.

Hakkinen, P. (2002). Challenges for design of computer-based learning environments. British Journal of Educational Technology, 33(4), 461-469.

Hannafin, M. J. (1993). Emerging technologies, ISD and learning environments critical perspectives. Educational Technology Research and Development, 40(1), 49-63.

Heacox, D. (2002). Differentiating instruction in the regular classroom: How to reach and teach all Learners. ABD: Free Spirit Publishing.

Henderson, L. (1996). Instructional design of interactive multimedia: A cultural critique. Educational Technology Research and Development, 44(4), 85-104.

Hoogveld, A. W. M., Paas, F., \& Jochems, W. M. G. (2005). Training higher education teachers for instructional design of competency-based education: Product-oriented versus processoriented worked examples. Teaching and Teacher Education, 21(2005), 287-297.

Hoogveld, A. W. M., Paas, F., Jochems, W. M. G., \& Van Merrienboer, J. J. G. (2002). Exploring teachers' instructional design practices from a systems perspective. Instructional Science, 30 , 291-305.

Hoven, D. (1999). A model for listening and viewing comprehension in multimedia environments. Language Learning \& Technology, 3(1), 88-103.

Hsu, T. C., Lee-Hsieh, J., Turton, M. A., \& Cheng, S. F. (2014). Using the ADDIE model to develop online continuing education courses on caring for nurses in Taiwan. The Journal of Continuing Education in Nursing, 45(3), 124-31.

Huang, W. H., Huang, W. Y., \& Tschopp, J. (2010). Sustaining iterative game playing processes in DGBL: The relationship between motivational processing and outcome processing. Computers \& Education, 55(2010), 789-797.

Huang, W., \& Johnson, J. (2002). Motivational level of a computer-based simulation: a formative evaluation of the US Army Recruiting Simulation (USAREC). Paper presented at the Annual Convention of the Association for Educational Communication and Technology, Dallas, TX.Hung, W. (2006). The 3C3R model: A conceptual framework for designing problems in PBL. Interdisciplinary Journal of Problem-based Learning, 1(1), 55-77.

Huang, W., Huang, W., Diefes-Dux, H., \& Imbrie, P. K. (2006). A preliminary validation of attention, relevance, confidence and satisfaction model-based instructional material motivational survey in a computer-based tutorial setting. British Journal of Educational Technology, 37(2), 243-259.

Jonassen, D. H. (1997). Instructional design models for well-structured and ill-structured problemsolving learning outcomes. Educational Technology Research and Development, 45(1), 65-94.

Jonassen, D. H., McAleese, T. M. R., \& Duffy, T. M. (1993). A Manifesto for a constructivist approach to technology in higher education. In T. M. Duffy, J. Lowyck, \& D. H. Jonassen (Eds.) The design of constructivistic learning environments: Implications for instructional design and the use of technology. Heidelburg, Germany: Springer-Verlag. Retrieved from http://link.springer.com/chapter/10.1007/978-3-642-78069-1_12

Karasar, N. (2012). Scientific research method. Ankara, Turkey: Nobel Publications. 
Keller, J. M. (1979). Motivation and instructional design: A theoretical perspective. Journal of Instructional Development, 2(4), 26-34.

Keller, J. M. (1983). Motivational design of instruction. In C. M. Reigeluth (Ed.), Instructional design theories and models: An overview of their current status (pp. 386-434). Hillsdale, NJ: Erlbaum.

Keller, J. M. (1984). The use of the ARCS model of motivation in teacher training. In K. Shaw \& A. J. Trott (Eds.), Aspects of educational technology, Vol. XVII (289-320). London: Kogan Page.

Keller, J. M. (1987a). Strategies for stimulating the motivation to learn. Performance and Instruction, 26, 1-7.

Keller, J. M. (1987b). The systematic process of motivational design. Performance and Instruction, 26(9-10), 1-8.

Keller, J. M., \& Kopp, T. W. (1987). An application of the ARCS model of motivational design. In C. M. Reigeluth (Ed.), Instructional theories in action: Lessons illustrating selected theories and models (289-320). Hillsdale, NJ: Erlbaum.

Khodabandelou, R., \& Abu Samah, S. A. (2012). Instructional design models for online instruction: From the perspective of Iranian higher education. Procedia-Social and Behavioral Sciences, 67(2012), 545-552.

Kirkpatrick, D. L. (1975). Evaluating training programs: A collection of articles from the Journal of the American Society for Training and Development. Madison, WI: American Society for Training and Development.

Kolb, A. D. (1984). Experiential learning: Experience as the source of learning and development. Englewood Cliffs, NJ: Prentice Hall. Retrieved from: http://academic.regis.edu/ed205/Kolb.pdf

Laurillard, D. M. (1993). Rethinking university teaching: A framework for the effective use of educational technology. London: Routledge.

Laverde, A. C., Cifuentes, Y. S., \& Rodriguez, H. Y. R. (2007). Toward an instructional design model based on learning objects. Educational Technology Research and Development, 55, $671-681$.

Lee, C. J., \& Kim, C. (2014). Implementation study of a TPACK-based instructional design model in a technology integration course. Educational Technology Research \& Development, 62(4), 437-460.

Lee, C. S., \& Kolodner, J. L. (2011). Scaffolding students' development of creative design skills: A curriculum reference model. Educational Technology \& Society, 14(1), 3-15.

Lee, J., \& Jang, S. (2014). A methodological framework for instructional design model development: Critical dimensions and synthesized procedures. Educational Technology Research and Development. Retrieved from http://link.springer.com/article/10.1007/ s11423-014-9352-7

Levinson, A. J. (2010). Where is evidence-based instructional design in medical education curriculum development? Medical Education, 44, 536-537.

Li, H. (2003). An investigation of a new instructional design procedure for web-based instruction: A Delphi study. Dissertation Abstracts International, 64(07). (UMI No. AAT 3097823)

Lin, J. L., Cheng, M. F., Chang, Y. C., Li, H. W., Chang, J. Y., \& Lin, D. M. (2014). Learning activities that combine science magic activities with the 5E instructional model to influence secondary-school students' attitudes to science. Eurasia Journal of Mathematics, Science \& Technology Education, 10(5), 415-426.

Main, R. G. (1993). Integrating motivation into the instructional design process. Educational Technology, 33(12), 37-41. 
McLoughlin, C. (1999). Culturally responsive technology use: Developing an on-line community of learners. British Journal of Educational Technology, 30(3), 231-243.

McManus, T. F. (1996). Delivering instruction on the World Wide Web (Unpublished manuscript). University of Texas, Austin.

Merrill, M. D. (2002). First principles of instruction. Educational Technology Research and Development, 50(3), 43-59.

Meyen, E. L., Aust, R. J., Bui, Y. N., Ramp, E., \& Smith, S. J. (2002). The Online Academy formative evaluation approach to evaluating online instruction. Internet and Higher Education, $5,89-108$.

Mishra, P., \& Koehler, M. J. (2006). Technological pedagogical content knowledge: A new framework for teacher knowledge. Teachers College Record, 108(6), 1017-1054.

Moallem, M. (2003). An interactive online course: A collaborative design model. Educational Technology Research and Development, 51(4), 85-103.

Morrison, G. R., Ross, S. M., \& Kemp, J. E. (2004). Designing effective instruction. Hoboken, NJ: John Wiley \& Sons.

Nadolski, R. J., Kirschner, P. A., van Merriënboer, J. J. G., \& Hummel, H. G. K. (2001). A model for optimizing step size of learning tasks in competency-based multimedia practicals. Educational Technology Research and Development, 87(103), 1042-1629.

Norum, K. E. (2000). Appreciative instructional design (AID): A new model. Paper presented at the Association for Educational Communications and Technology National Conference, Long Beach, CA.

Passerini, K., \& Granger, M. J. (2000). A developmental model for distance learning using the Internet. Computers \& Education, 34(1), 1-15.

Pearson, L. C., \& Carey, L. M. (1995). The academic motivation profile for undergraduate student use in evaluating college courses. The Journal of Educational Research, 88(4), 220-227.

Plass, J. L., \& Salisbury, M. W. (2002). A living-systems design model for web-based knowledge management systems. Educational Technology Research and Development, 50(1), 35-57.

Posner, G. J., \& Rudnitsky, A. N. (2001). Course design: A guide to curriculum development for teachers. New York: Addison Wesley Longman, Inc.

Reigeluth, C. M. (1983). Instructional design: What is it and why is it? In C. M. Reigeluth (Ed.), Instructional design theories and models: An overview of their current status (3-35). Hillsdale, NJ: Erlbaum.

Reigeluth, C. M. (1987). Instructional theories in action: Lessons illustrating selected theories and models. Hillsdale, NJ: Erlbaum.

Reigeluth, C. M., \& Stein, R. (1983). Elaboration theory. In C. M. Reigeluth (Ed.), Instructional design theories and models: An overview of their current status. Hillsdale, NJ: Erlbaum.

Richey, R., \& Nelson, W. (1996). Developmental research. In D. H. Jonassen (Ed.), Handbook of research for educational communications and technology (1213-1245). New York: Macmillan.

Rourke, L., \& Szabo, M. (2002). A content analysis of the Journal of Distance Education 19862001. Journal of Distance Education, 17(1), 63-74.

Royal, C. (2007). Exploring the use of Instructional Design Models for web-based Instruction in Higher Education: A modified delphi study (Doctoral dissertation). Available from Proquest Dissertations and Theses database. (UMI No. AAT 3274760)

Seels, B. B., \& Richey, R. C. (1994). Instructional technology: The definition and domains of the field. Washington, DC: Association for Educational Communications and Technology. 
Shambaugh, N., \& Magliaro, S. (2001). A reflexive model for teaching instructional design. Educational Technology Research and Development, 49(2), 69-92.

Shulman, L. S. (1986). Those who understand: knowledge growth in teaching. Educational Researcher, 15, 4-14.

Sims, R., \& Jones, D. (2003). Where practice informs theory: Reshaping instructional design for academic communities of practice in online teaching and learning. Information Technology, Education and Society, 4(1), 3-20.

Şimşek, A. (2011). Instructional design. Ankara, Turkey: Nobel Academic Publications.

Şimşek, A. (2013). Instructional design and models. In K. Çağıltay (Eds.), The principles of instructional technology: Theory, research, trends (99-116). Ankara, Turkey: Pegem Academy.

Small, R. V. (2000). Motivation in instructional design. Teacher Librarian, 27(5), 29-31.

Small, R. V., \& Gluck, M. (1994). The relationship of motivational conditions to effective instructional attributes: A magnitude scaling approach. Educational Technology, 34(8), 33-40.

Smith, P. L., \& Ragan, T. J. (1993). Instructional design. Upper Saddle River, NJ: Merrill.

Smith, P. L., \& Ragan, T. J. (1999). Instructional design. New York: Macmillan.

Squire, K. D. (1999). Opportunity initiated systems design. System Practice and Action Research, 12(6), 633-648.

Stevens, F. C. J., \& Goulbourne, J. D. S. (2012). Globalization and the modernization of medical education. Medical Teacher, 34, e684-e689.

Strickland, A. W. (2006). ADDIE. Retrieved from http://web.archive.org/web/ 20060709154016/http://ed.isu.edu/addie/index.html

Sweller, J. (1988). Cognitive load during problem solving: Effects on learning. Cognitive Science, 12(2), 257-285.

Tracey, M. W., \& Richey, R. C. (2007). ID model construction and validation: A multiple intelligences case. Educational Technology Research and Development, 55(4), 369-390.

Tripp, S., \& Bichelmeyer, B. (1990). Rapid prototyping: An alternative instructional design strategy. Educational Technology Research and Development, 38(1), 31-44.

Valiathan, P. (2010). Instructional design. Training Journal. Retrieved from http://www.trainingjournal.com/feature/2010-01-01-instructional-design/

van Harmelen, H. (2008). Design trajectories: Four experiments in PLE implementation. Interactive Learning Environments, 16(1), 36-46.

van Merrienboer, J. J. G., Clark, R. E., \& de Croock, M. B. M. (2002). Blueprints for complex learning: The 4C/ID-model. Educational Technology, Research and Development, 50(2), 3964.

Visscher-Voerman, I., \& Gustafson, K. L. (2004). Paradigms in the theory and practice of education and training design. Educational Technology Research and Development, 52(2), 6989.

Watson, R. (1981). Instructional system development. Paper presented to the International Congress for Individualized Instruction. Retrieved from ERIC database. (ED209239)

Wiggins, G. P., \& McTighe, J. (1998). Understanding by design. Alexandria, VA: Association for Supervision and Curriculum Development (ACSD).

Woo, J. C. (2014). Digital game-based learning supports student motivation, cognitive success, and performance outcomes. Educational Technology \& Society, 17(3), 291-307. 
Young, P. A. (2008). The culture based model: Constructing a model of culture. Educational Technology \& Society, 11(2), 107-118.

Zheng, L., \& Smaldino, S. (2003). Key instructional design elements for distance education. The Quarterly Review of Distance Education, 4(2), 153-166.

Copyright @ 2017 Idris Göksu, Kursat Volkan Özcan, Recep Çakir and Yuksel Göktas 